\title{
Determination of the binding mechanism of cobalt(II) meso-tetraphenyl porphyrin with plant-esterase
}

\author{
Zishan Liu ${ }^{1,2}$, Liang Dong1, *, Feifeng $\mathrm{Li}^{1}$, Changjun $\mathrm{Hou}^{2,}$, Kun $\mathrm{He}^{2}$, Danqun $\mathrm{Huo}^{2,}$ * \\ ${ }^{1}$ Sichuan University of Science \& Engineering, Zigong 643000, China \\ ${ }^{2}$ Key Laboratory of Biorheology Science and Technology, Ministry of Education, College of Bioengineering, Chongqing \\ University, Chongqing 400044, China \\ "Corresponding author: e-mail: dongliang@suse.edu.cn; houcj@cqu.edu.cn; huodq@cqu.edu.cn
}

\begin{abstract}
Plant-esterase (EC 3.1.1.X) has received much attention because plant esterase and acetylcholinesterase (AChE) share a similar sensitivity towards organophosphorus (OP) pesticides detection with the same inhibition mechanism. To improve the analytical performance, tetraphenyl metal porphyrin, as an indicator was introduced to combine with plant-esterase. The time of reach equilibrium in PBS solution was shortened after adding plant-esterase by assaying the intensify change of the porphyrin spectrum. Meanwhile, intensify of porphyrin spectrum with plant-esterase was increased compared with that of only the porphyrin spectrum in solution. Tetraphenyl metal porphyrin, such as cobalt(II) meso-tetraphenyl porphyrin, is a mixed reversible inhibitor of plant-esterase from kinetic parameters. The combination ratio of plant-esterase and porphyrin is 2:1. On the other hand, the interaction between CoTPPCl and plant-esterase is the strongest among all tested tetraphenyl metal porphyrin. And the mixed system (CoTPPClplant-esterase) showed the best sensitivity towards the tested pesticide. All these results indicated that a complex system composed of tetraphenyl metal porphyrin and plant-esterase was fit for detecting pesticides. They make meaningful guidance on the further design of sensing material in monitoring pesticides.
\end{abstract}

Keywords: plant-esterase, tetraphenyl metal porphyrin, binding mechanism.

\section{INTRODUCTION}

Acetylcholinesterase (AChE) is a highly sensitive bio-recognition element for the inhibition of organophosphorus, carbamate pesticides and is widely studied in the past decades ${ }^{1}$. However, the high cost and low accessibility of AChE (extracted from animal blood or tissue) greatly limit its wide application. In recent years, plant esterase (EC 3.1.1.X) as a substitute for AChE has attracted wide attention due to its similar sensitivity towards organophosphorus (OP) pesticides and inhibition mechanism. In addition, the extraction of plant esterase from wheat, soybean, rice, sorghum and other plants is not only cost-effective, but also easy to obtain ${ }^{1}$, which enable its great potential in pesticide detection.

However, the study of plant-esterase is not very well-rounded. The nature substrate of plant-esterase is still unsure. The mimic substrate may reduce plant-esterase activity and have negative effects on the sensitivity of the biosensor. Furthermore, it is cumbersome to introduce substrate, chromogenic reagent and stabilizer in the process of enzyme activity assay. Thus, avoiding the enzyme activity assay is an important way to improve sensitivity and shorten detection time. Except for the change of enzyme activity, the structure of enzyme will be change after the detection. Thus, a suitable structure indicator also indirectly reflects the existing pesticide.

Porphyrin is a colored molecule with a high degree of conjugation and displays rich photophysical properties ${ }^{1}$. Its absorbance spectrum is sensitive to the change of environment. Changes in acidity $^{2}$, hydrophobicity ${ }^{3}$ and ion content ${ }^{4}$ can result in a difference of absorbance intensity. Relay on this characteristic, Harmon ${ }^{5}$ chose water-soluble porphyrin as an indicator combined with cholinesterase to detect pesticides. It has been proven that porphyrin compounds are chromogenic reagents which can be indicated the microenvironment changes. In our early study, plant-esterase and monosulfonate tetraphenyl porphyrin were combined as a complex material. It can be effectively detected dimethyl methyl-phosphonate within 3 or $5 \mathrm{~s}^{6}$. Nevertheless, most of the study is related to water-soluble porphyrin. Komatsu ${ }^{7}$ proposed the stability of non-soluble porphyrin in the aqueous phase will be improved after adding protein or enzyme. Non-soluble porphyrin, especially non-water-soluble metal porphyrin, is prone to enter the hydrophobic active site of enzyme and combine to the imidazole of amino acids with coordination bond. Meanwhile, Hou et $\mathrm{al}^{8}$ has proven the plant-esterase is a metal ion-dependent enzyme. Thus, tetraphenyl metal porphyrin, the simplest structure of non-water-soluble metal porphyrins is a promising alternative as a chromogenic reagent in our research. Here, we study the interaction between plant-esterase and tetraphenyl metal porphyrin in PBS solution. The complex system is also used to detect carbendazim by its spectrophotometric change.

\section{MATERIALS AND METHODS}

\section{Plant-esterase preparation}

Wheat flour (Guowei, Anhui) was purchased from the supermarket in Chongqing, China. The wheat flour was made to obtain pure plant-esterase according to the procedure described by Yang et $\mathrm{al}^{9}$. In brief, crude plant-esterase was extracted from a solution of wheat flour $(1: 5 \mathrm{w} / \mathrm{w})$ by using centrifuged at $4000 \mathrm{r} / \mathrm{min}$ and $4^{\circ} \mathrm{C}$ for $10 \mathrm{~min}$. Then it was purified with a PEG1000/ $\mathrm{NaH}_{2} \mathrm{PO}_{4}$ aqueous two-phase system by a two-step extraction. To obtain its powder, the purified plant-esterase underwent dialysis and then was freeze-dried at $-50^{\circ} \mathrm{C}$.

\section{Enzyme assays}

The plant-esterase activity was measured by the method according to the previous report ${ }^{10}$. In detail, $0.5 \mathrm{~mL}$ of enzyme solution was mixed with 1-naphthyl acetate 
(16 mM, $50 \mu \mathrm{L}$ ) (Yuanju, Shanghai) as a substrate in $1.95 \mathrm{~mL}$ phosphate buffer ( $\mathrm{pH}$ 6.5). After $5 \mathrm{~min}$ of incubation at $40^{\circ} \mathrm{C}, 0.5 \mathrm{~mL}$ Fast Blue B salt (Yuanju, Shanghai)-SDS solution and $0.1 \mathrm{~mL} \mathrm{HCl} \mathrm{(6} \mathrm{M)} \mathrm{was}$ added. Finally, the absorbance was detected at $535 \mathrm{~nm}$ using a spectrophotometer (PerkinElmer Instruments, USA). One enzyme activity unit was defined as the amount of enzyme hydrolyzing $1 \mu$ mol of 1-naphthyl acetate per minute under the standard assay conditions.

\section{Effect of plant-esterase on porphyrin}

The enzyme was incubated at $25^{\circ} \mathrm{C}$ with $5 \mu \mathrm{M}$ various tetraphenyl metal porphyrin (CoTPPCl, ZnTPP, FeTPPCl, EuTPPCl, InTPP and TPP) respectively. After reactions reached equilibrium, Soret intensities changes of porphyrin in the presence or absences of enzyme in solution were recorded.

\section{Effect of CoTPPCI on plant-esterase}

Purified plant-esterase was mixed with various concentrations of $\mathrm{Co}^{3+}$, CoTPPCl, TPP from $2.5 \mu \mathrm{M}$ to 15 $\mu \mathrm{M}$ in PBS, $\mathrm{pH} 6.5$, at $25^{\circ} \mathrm{C}$. Then the residual enzyme activity was assayed with the standard method mentioned above after $30 \mathrm{~min}$. Discrete concentrations of CoTPPCl solution (4 to $12 \mathrm{mM}$ ) were respectively mixed with discrete concentrations of enzyme solution $\left(5 \times 10^{-8} \mathrm{M}\right.$ to $250 \times 10^{-8} \mathrm{M}$ ). After $30 \mathrm{~min}$, the specific activity was determined by the standard method. The enzyme activity was assayed after changing concentrations of the substrate from $0.01 \mathrm{M}$ to $2.0 \mathrm{M}$. Then the Lineweaver-Burk plot of plant-esterase was described.

\section{Detection of different complex system}

The enzyme solution was incubated at $25^{\circ} \mathrm{C}$ with $5 \mu \mathrm{M}$ various tetraphenyl metal porphyrin (CoTPPCl, ZnTPP, FeTPPCl, EuTPPCl, InTPP and TPP) respectively. After reaction equilibrium, different concentrations of carbendazim $\left(5.23 \times 10^{-6} \mathrm{M}\right.$ to $\left.5.23 \times 10^{-10} \mathrm{M}\right)$ were mixed with complex systems. According to the spectrum changes, the detection result would be analyzed.

\section{RESULT AND DISCUSSION}

\section{Changes of porphyrin spectrum}

As shown in Fig. 1, the absorbance strength of porphyrin spectrum was increased with various degrees and peaks of porphyrin spectrum were moved after adding plant-esterase. The detailed changes information was listed in Table 1. There is no change in absorbance wavelength for InTPPCl and EuTPPCl and a significant red-shift of $28 \mathrm{~nm}$ for CoTPPCl after the addition of plant esterase. Besides, absorbance strength enhancements were observed with different degrees upon the addition of plant esterase. Among them, CoTPPCl displayed the biggest response of 0.12. In Fig. 2, in the presence of plant-esterase, porphyrin spectrum tends to be stable after 25 min. Comparison by the absence of plant-esterase, porphyrin spectrum keeps down after $25 \mathrm{~min}$. The data were summarized in Table 1.

After reaction with plant-esterase, peaks absorbance of $\mathrm{CoTPPCl}$ and FeTPPCl were red-shift. Peaks absorbance of TPP and ZnTPP were blue-shift. While that of EuTPP and InTPP were not changed. Among metal ion above, $\mathrm{Zn}^{2+}, \mathrm{Fe}^{3+}$ and $\mathrm{Co}^{3+}$ were classified as transition metal ions.
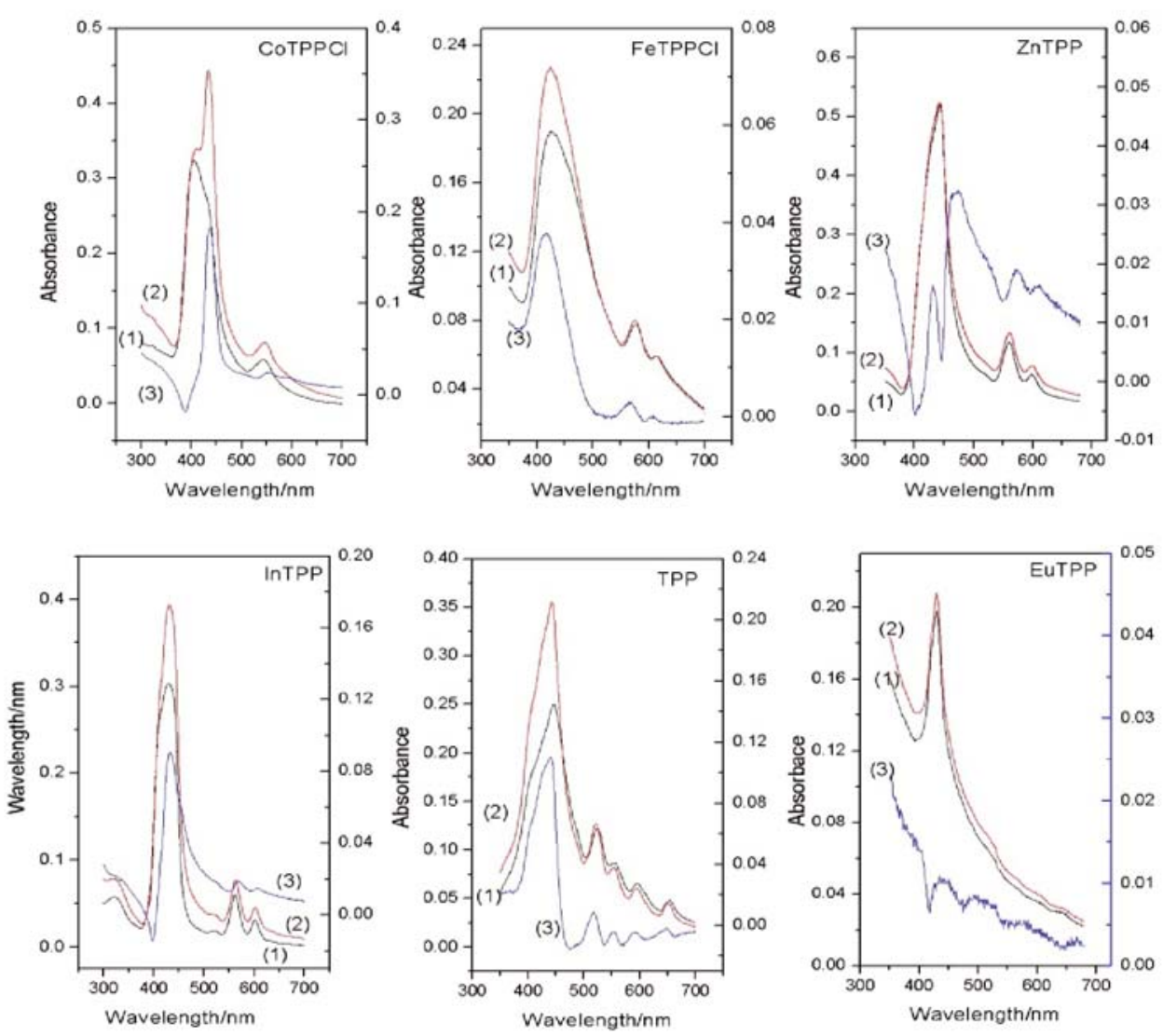

Figure 1. Absorption peak of porphyrin with the presence (Trace 1) and absence (Trace 2) of plant-esterase. Trace 3 represents the difference spectrum Trace 2 minus Trace 1 

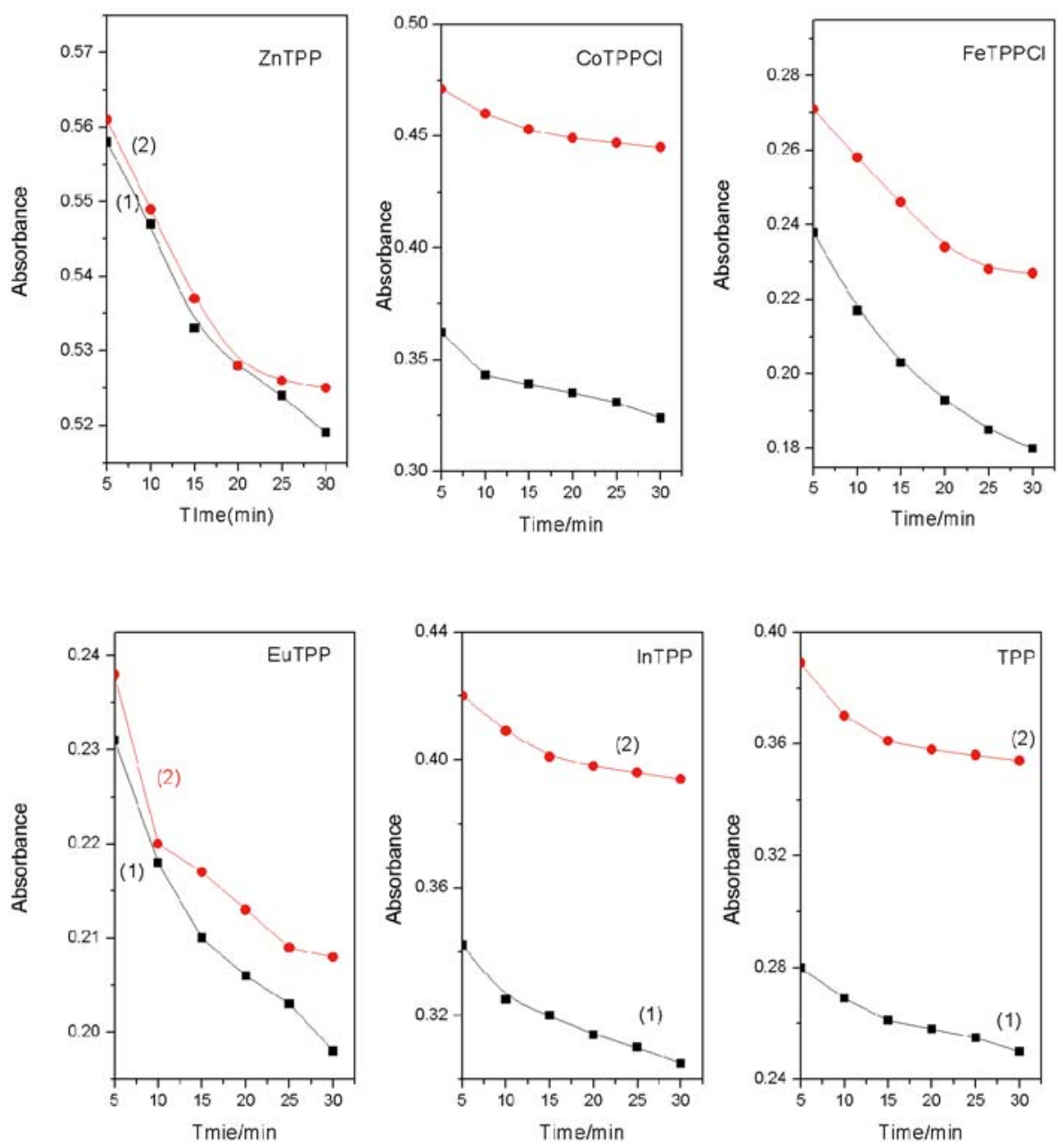

Figure 2. Changes of porphyrin spectrum with the (1) absence and (2) presenceand of plant-esterase. The absorbance recorded at various wavelength: ZnTPP: 444 nm, 442 nm; CoTPPCl: 406 nm, 434 nm; FeTPPCl: 423 nm, 425 nm; EuTPPCl: 429 nm, 429 nm; InTPPCl: $431 \mathrm{~nm}, 431 \mathrm{~nm}$; TPP: 446 nm, $444 \mathrm{~nm}$ (before: left, after: right)

After reaction with the enzyme, Soret bands were changed. While, $\mathrm{Eu}^{2+}$ and $\mathrm{In}^{2+}$ were not included in transition metal ions, thus the position of their sort band did not change. Among these changes, the maximum extent of change was CoTPPCl whose atomic radius is largest among referred transition metal ions. It is speculated the size of $\mathrm{Co}^{3+}$ is suitable for the cavity of plant-esterase. Thus, the reaction between them is much more severe than others. The nitrogen atoms of amino and the hydroxyl oxygen atom of carboxyl in plant-esterase carry some electronics. These electronics would transfer to the porphyrin. Based on the types of metal ions, the degree of transfer has some differences. The electron-withdrawing ability of trivalent metal ions is much stronger than that of divalent metal ions. When trivalent metal tetraphenyl porphyrin interacts with plant-esterase, electron would flow from porphyrin to enzyme. The electron cloud density of porphyrin would be reduced and its Soret band appeared red-shift. The direction of electrons flow

Table 1. Spectral respond of plant-esterase-metal-porphyrins leads to the opposite result to arise in divalent metal tetraphenyl porphyrin. The spectrum change of TPP and ZnTPP are similar. Because ZnTPP belongs adductoring tetraphenyl metal porphyrin. Its spectroscopic property is similar to tetraphenyl porphyrin.

Another way, the time of tetraphenyl porphyrin reach to balance in PBS was shorten with the presence of plant-esterase. And the peak shape of tetraphenyl porphyrin mixed with plant-esterase is similar to that of tetraphenyl porphyrin in DMF, except for peak position. Thus plant-esterase provides a hydrophobic environment for terrapheynyl porphyrin, and it enhances the stability of hydrophobic porphyrin in aqueous solutions.

\section{Effect on enzyme activity}

Impacts of $\mathrm{Co}^{3+}, \mathrm{CoTPPCl}$ and TPP on the activity of plant-esterase were displayed on Fig. 3. The inhibition of TPP on the enzyme is much more serious than that of CoTPPCl. The concentrations of CoTPPCl and TPP

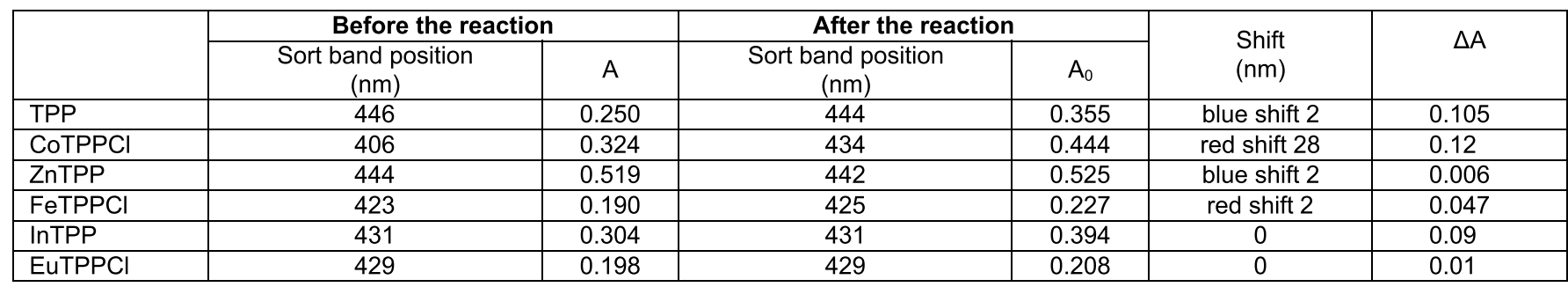


are $1.5 \times 10^{-6} \mathrm{M}$, relative activities are $48.9 \%$ and $43.8 \%$ respectively. While $\mathrm{Co}^{3+}$ at the same range of concentration acted as activators in increasing the activity of plant-esterase. Especially when the concentration of $\mathrm{Co}^{3+}$ reached $7.5 \times 10^{-6} \mathrm{M}$, activation intensify is the most obvious. Thus, from the data of enzyme activity, the

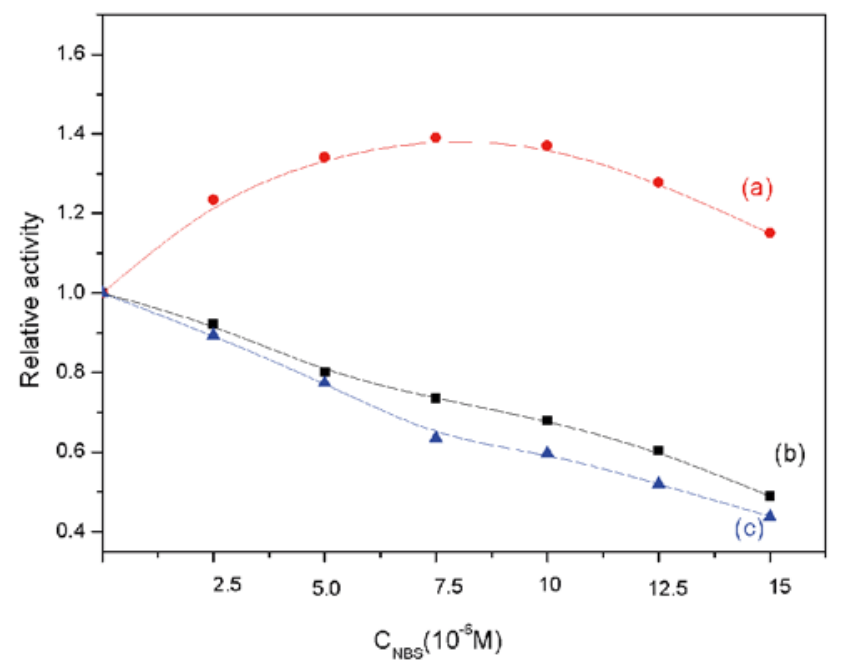

Figure 3. The influence of (a) $\mathrm{Co}^{3+}$, (b) $\mathrm{CoTPPCl}$, (c) TPP on the activity of plant-esterase

effect of CoTPPCl on plant-esterase seems to combine the effects of both TPP and $\mathrm{Co}^{3+}$.

Then specific activities of different concentrations enzyme are shown in Fig 4. With concentrations of plant-esterase increased, the specific activity of each sample increased. No matter which concentration of plant-esterase, values of specific activities are nearly through the origin. Further, with a decrease of CoTPPCl concentrations, slopes of line were decreased. It illustrates that decreasing the activity of plant-esterase caused by increasing $\mathrm{CoTPPCl}$ is rooted form inhibition of enzyme

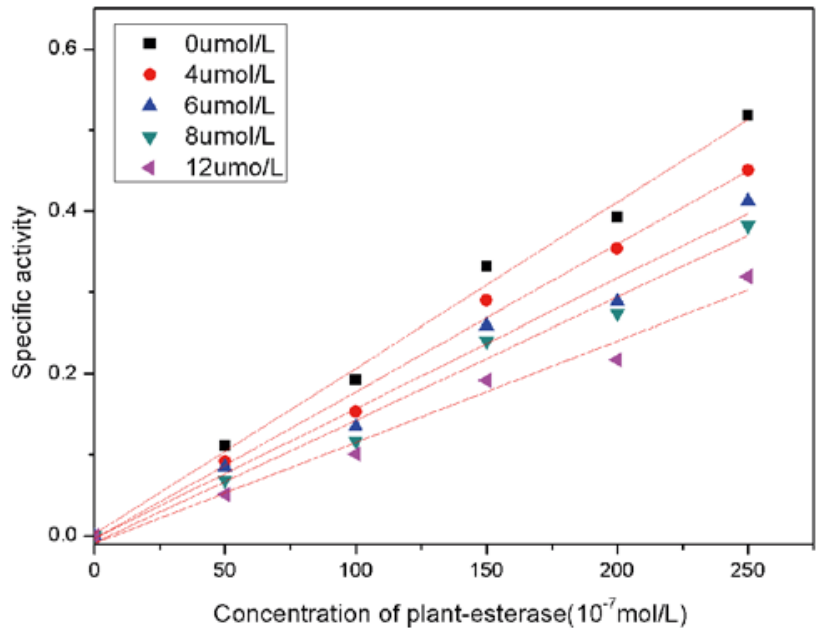

Figure 4. Effects of different enzyme concentrations on its activity

activity, rather than decreasing enzyme concentrations. Thus, CoTPPCl is a reversible inhibitor of plant-esterase.

At last, Lineweaver-Burk plot was used to exploit the type of reversible inhibition. From equations in Fig. 5, after the reaction with $\mathrm{CoTPPCl}$, the value of $\mathrm{Km}$ was increased and the value of Vmax was decreased. It means that CoTPPCl can combine with plant-esterase no matter whether the substrate is present or not. Thus, CoTPPCl is a mixed reversible inhibitor of plant-esterase. This conclusion is also used to illustrate the change of porphyrin spectrum. Porphyrins would lead the conformational

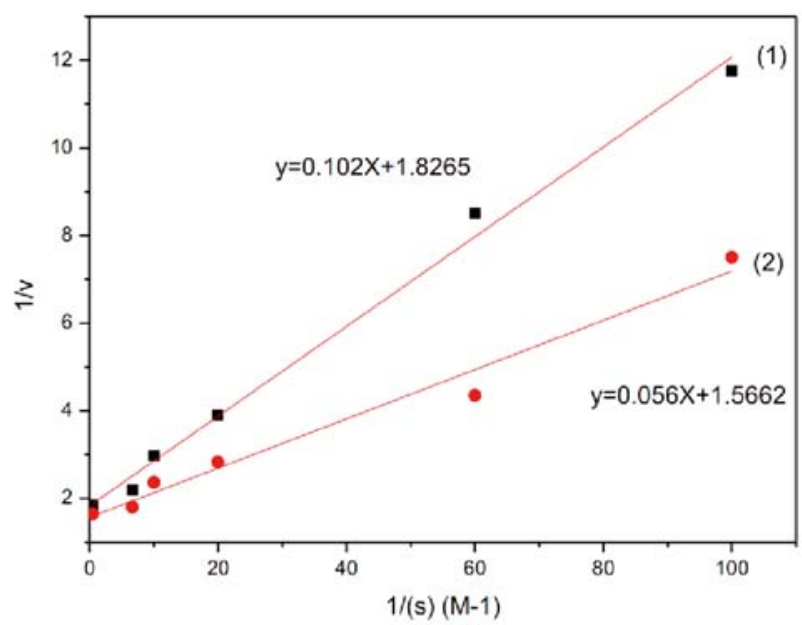

Figure 5. The Lineweaver-Burk plot of plant-esterase (1) the presence of CoTPPCl (2) the absence of CoTPPCl

changes of plant-esterase ${ }^{\mathbf{1 1}}$, while plant-esterase would have an impact on electronic distribution of porphyrin.

\section{Interaction between plant-esterase and CoTPPCI}

The spectrophotometric studies on increasing CoTP$\mathrm{PCl}$ concentration showed in Fig 6. With different concentrations of $\mathrm{CoTPPCl}$, intensify of plant-esterase spectrum is different. The binding affinity constant $\mathrm{K}$ was calculated from the change of plant-esterase at 208 $\mathrm{nm}$ using the relation ${ }^{\mathbf{1 2}}$ :

$A_{0 / \Delta A}=A_{0 / \Delta A_{\max }}+A_{0} / \Delta A_{\max } \cdot 1 / K \cdot 1 / L_{t}$

Where $\Delta \mathrm{A}=\mathrm{A}_{0}-\mathrm{A}, \mathrm{A}_{0}$ and $\mathrm{A}$ represent the absorption intensities of plant-esterase at $208 \mathrm{~nm}$ in the absence and presence of CoTPPCl concentration $\left(\mathrm{L}_{\mathrm{t}}\right) \cdot \Delta \mathrm{A}_{\max }$ is

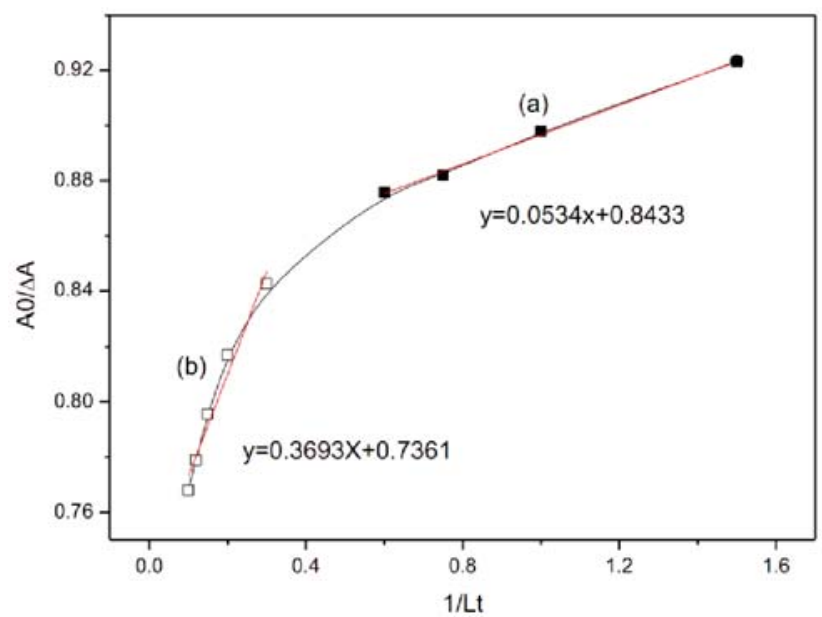

Figure 6. Estimation of the binding affinity constant in the interaction of Plant-esterase with CoTPPCl (a) The concentration of plant-esterase from $0.67 \mu \mathrm{M}$ to 1.67 $\mu \mathrm{M}$ (b) The concentration of plant-esterase from 3.3 $\mu \mathrm{M}$ to $10 \mu \mathrm{M}$ 
the maximum change of absorption value. The slopes of plots provide affinity constant, which are summarized in Table 2.

The possible numbers of binding sites were also calculated from the plot of $1 / 1-\theta$ versus $L_{t} / \theta$ (Fig. 4) for CoTPPCl-plant-esterase interaction following the relation:

$1 / 1-\theta=\mathrm{KL}_{\mathrm{t}} / \theta-\mathrm{K} \cdot \mathrm{P} \cdot \mathrm{A}_{\mathrm{t}}$

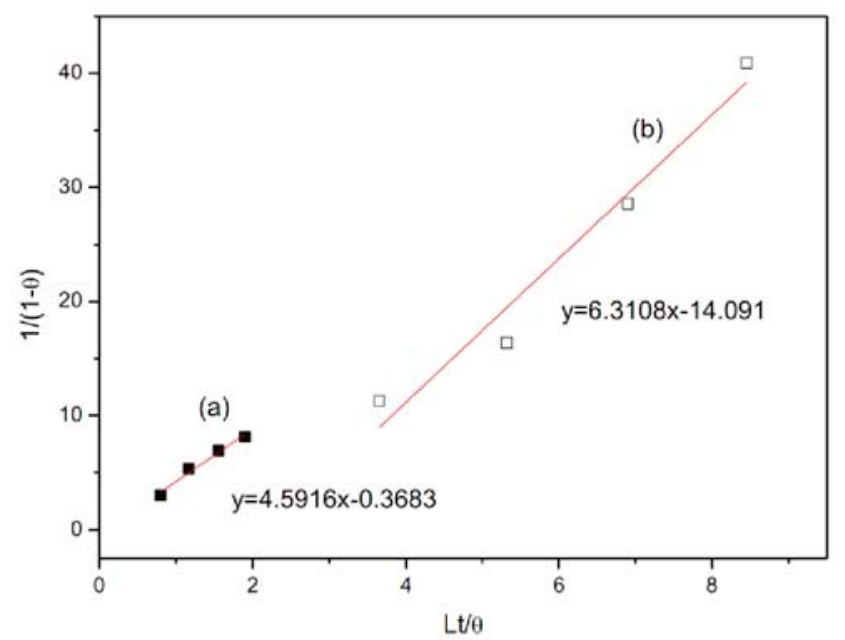

Figure 7. Estimation of the possible number of binding sites involved in the interaction of Plant-esterase with CoTPPCl (a) The concentration of plant-esterase from $0.67 \mu \mathrm{M}$ to $1.67 \mu \mathrm{M}$ (b) The concentration of plant-esterase from $3.3 \mu \mathrm{M}$ to $10 \mu \mathrm{M}$

Table 2. Estimated values of binding affinity constant $(\mathrm{K})$ and possible number o binding sites $(\mathrm{P})$ for binding of plant-esterase with CoTPPCl

\begin{tabular}{|c|c|c|}
\hline $\begin{array}{c}\text { CoTPPCl } \\
\text { concentration }(\mu \mathrm{M})\end{array}$ & $\begin{array}{c}\text { Binding Affinity } \\
\text { Constant } \mathrm{K}\left(\times 10^{5} \mathrm{M}^{-1}\right)\end{array}$ & $\begin{array}{c}\text { Number of } \\
\text { Binding Sites }(\mathrm{P})\end{array}$ \\
\hline $0.67-1.67$ & 15.79 & 0.08 \\
\hline $3.3-10$ & 1.99 & 2.23 \\
\hline
\end{tabular}

where $\theta=\Delta \mathrm{A} / \Delta \mathrm{A}_{\max }, \mathrm{p}=$ plant-esterase concentration

The calculated number of binding sites was summarized in Table 2

\section{Detection results from different complex system}

The spectral changes of CoTPPCl-plant-esterase in the absence and presence of carbendazim $\left(5.23 \times 10^{-7} \mathrm{M}\right)$ was shown in Fig. 8. The absorption intensity in Soret band of CoTPPCl was increased after reaction with carbendazim. The original balance of CoTPPCl-plant-esterase was broken by adding pesticide. The absorption intensity in $\mathrm{Q}$ band of CoTPPCl was decreased after detection with carbendazim. The symmetry of porphyrin molecule was increased, suggesting that the number of free porphyrin molecules was increased in solution. When the concentration changes of CoTPPCl from $8.3 \times 10^{-8}$ $\mathrm{M}$ to $5.23 \times 10^{-7} \mathrm{M}$, the absorbance value of $\mathrm{CoTPPCl}$
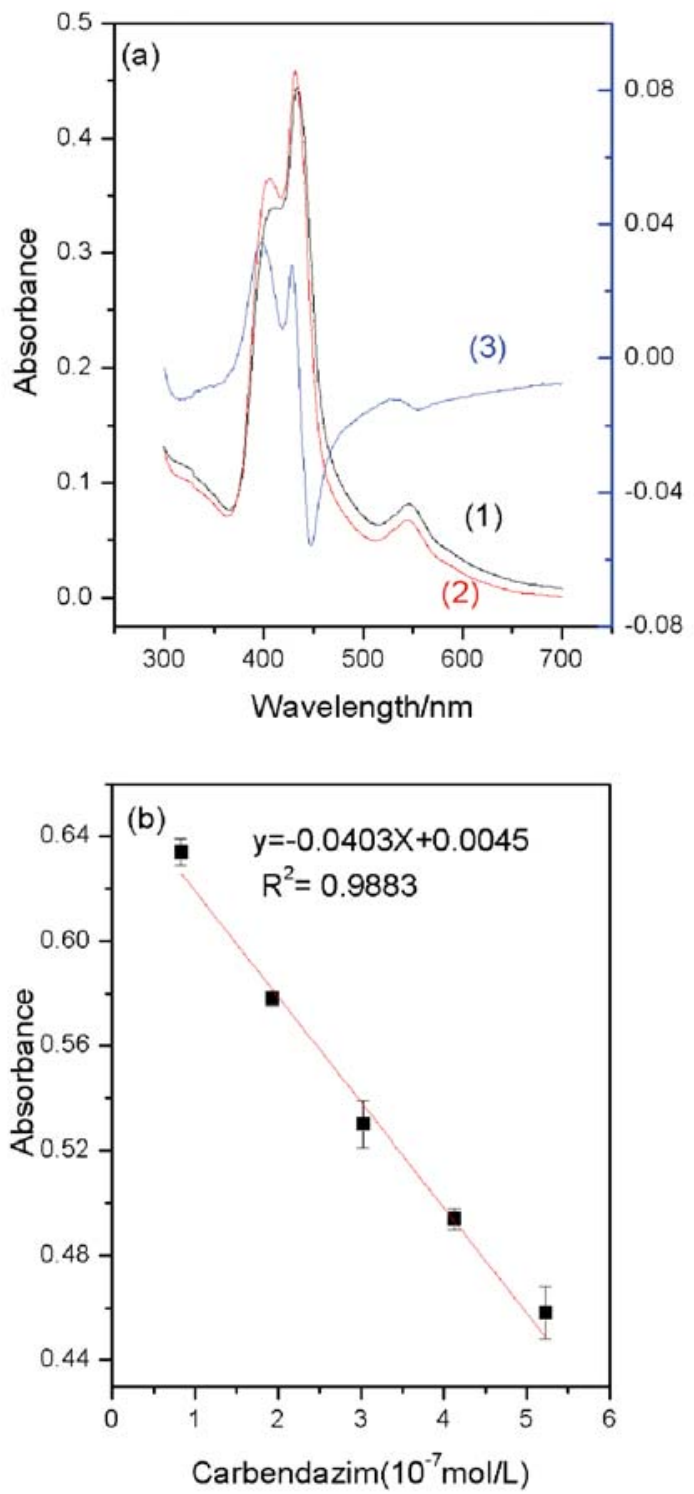

Figure 8. (a) Reaction between plant-esterase-CoTPPCl and $5.23 \times 10^{-7} \mathrm{~mol} / \mathrm{L}$ carbendazim. (b) Dependence on carbendazim concentration $\left(8.3 \times 10^{-8} \mathrm{~mol} / \mathrm{L}\right.$ $\left.-5.23 \times 10^{-7} \mathrm{~mol} / \mathrm{L}\right)$ of the $432 \mathrm{~nm}$ absorbance

in Soret band has liner relationship $\left(\mathrm{R}^{2}=0.9883\right)$ with the concentration of carbendazim.

The same tests did for changing different kinds of tetraphenyl metal porphyrin (ZnTPP, FeTPPCl, EuTPPCl, InTPP and TPP). The results were summarized in Table 3. Complex systems consisted of InTPP and EuTPP respectively are not very suited for the detection carbendazim. Because the absorbance value of both of them nearly did not change with the concentration change of carbendazim. Among them, CoTPPCl-plant-esterase complex shows the best sensitivity towards carbendazim. Combined with the conclusion from Fig. 1, the stronger

Table 3. Detection effect and spectral response of plant esterase-porphyrin against carbendazim

\begin{tabular}{|c|c|c|c|c|c|c|c|}
\hline \multirow{2}{*}{ Porphyrins } & \multirow{2}{*}{$\begin{array}{c}\text { Detection limit } \\
(\mathrm{M})\end{array}$} & \multirow{2}{*}{ Precision Sensitivity } & & \multirow{2}{*}{ Peak } & \multicolumn{3}{|c|}{ Difference spectrum } \\
\hline & & & & & $\Delta \mathbf{A}$ & Trough & $\Delta \mathbf{A}^{\prime}$ \\
\hline CoTPPCl & $5.23 \times 10^{-10}$ & 0.008 & 600 & $428 \mathrm{~nm}$ & 0.028 & $447 \mathrm{~nm}$ & -0.055 \\
\hline ZnTPP & $5.23 \times 10^{-9}$ & 0.003 & 190 & $428 \mathrm{~nm}$ & 0.099 & $448 \mathrm{~nm}$ & -0.076 \\
\hline FeTPPCl & $5.23 \times 10^{-8}$ & 0.005 & 137 & - & - & $417 \mathrm{~nm}$ & -0.0312 \\
\hline MnTPP & $5.23 \times 10^{-8}$ & 0.003 & 7.80 & $473 \mathrm{~nm}$ & 0.031 & - & - \\
\hline TPP & $5.23 \times 10^{-8}$ & 0.007 & 24.21 & - & - & $442 \mathrm{~nm}$ & -0.057 \\
\hline
\end{tabular}


intensity of action between porphyrin and esterase, the better detection performances would be obtained.

\section{CONCLUSION}

We explored the interaction between tetraphenyl metal porphyrin and plant-esterase. Plant-esterase plays the role of stabilizing and enhancing the strength porphyrin spectrum in PBS. It provides a hydrophobic environment for porphyrin. At the same time, tetraphenyl metal porphyrin, such as cobalt tetraphenyl porphyrin is a mixed reversible inhibitor of plant-esterase. The binding site of plant-esterase with $\mathrm{CoTPPCl}$ is nearly equal to 2 . Furthermore, the spectrum of complex solution displayed a promising potential for pesticides detection quantitatively.

\section{ACKNOWLEDGMENT}

The present study was supported by The Liquor Making Biological Technology \& Application of Key Laboratory of Sichuan Province NJ2019-04, Talent introduction project of Sichuan University of Science and Engineering(2018RCL24) and Key Laboratory of fine chemicals and surfactant in Colleges and universities of Sichuan Province(2018JXY05), Sichuan Science and Technology Department Project(2019YJ0463), Innovation and entrepreneurship training program for College Students of Sichuan University of Science and Engineering(S201 910622037;cx2019050;cx2020200).

\section{CONFLICT OF INTEREST STATEMENT}

The authors declared that they have no conflicts of interest to this work. We declare that we do not have any commercial or associative interest that represents a conflict of interest in connection with the work submitted.

\section{LITERATURE CITED}

1. Wang, M., Gu, X., Zhang, G., Zhang, D. \& Zhu, D. (2009). Continuous Colorimetric Assay for Acetylcholinesterase and Inhibitor Screening with Gold Nanoparticles. Langmuir, 25, 2504-2507. DOI: 10.1021/la803870v.
2. Kulikova, O.M., Ivanova, Y.B. \& Mamardashvili NZ. (2011). Determination of acidity of di-, tri-, and tetraazaporphyrins in dimethyl sulfoxide-potassium cryptate medium. Russ. J. Gen. Chem. 81, 602-606. DOI: 10.1134/S1070363211030285.

3. Roales, J., Pedrosa, J.M., Castillero, P., Cano, M. \& Richardson, T.H. (2011). Optimization of mixed Langmuir-Blodgett films of a water insoluble porphyrin in a calixarene matrix for optical gas sensing. Thin Solid Films. 519, 2025-2030. DOI: $10.1016 /$ j.tsf.2010.10.038.

4. Whittington, C.L., Maza, W.A., Woodcock, H.L. \& Larsen, R.W. (2012). Understanding Ion Sensing in Zn(II) Porphyrins: Spectroscopic and Computational Studies of Nitrite/Nitrate Binding. Inorg. Chem. 51, 4756-4762. DOI: 10.1021/ic300039v.

5. Harmon, H.J. (2008). Role of non-linear optics and multiple photon absorbance in enhancing sensitivity of enzyme-based chemical agent detectors. Methods., 46, 18-24. DOI: 10.1016/j. ymeth.2008.05.003.

6. Huo, D.Q., Yang, L.M. \& Hou, C.J. (2009). Optical Detection of Dimethyl Methyl-Phosphonate with Monosulfonate Tetraphenyl Porphyrin-Plant-Esterase Complex. Sensor Lett., 7, 72-78. DOI: 10.1166/sl.2009.1012.

7. Komatsu, T., Wang, R.M., Zunszain, P.A., Curry, S. \& Tsuchida, E. (2006). Photosensitized reduction of water to hydrogen using human serum albumin complexed with zinc-protoporphyrin IX. J. Amer. Chem. Soc., 128, 16297-16301. DOI: $10.1021 / \mathrm{ja} 0656806$.

8. Hou, C.J., He, K., Yang, L.M., Huo, D.Q., Yang, M., Huang, S., Zhang, L. \& Shen, C.H. (2012). Catalytic characteristics of plant-esterase from wheat flour. World J. Microbiol. Biotechnol., 28, 541-548. DOI: 10.1007/s11274-011-0845-9.

9.Yang, L.M, Huo, D.Q., Hou, C.J., He, K., Lv, F.J., Fa, H.B. \& Luo, X.G. (2010). Purification of plant-esterase in PEG1000/NaH2PO4 aqueous two-phase system by a two-step extraction. Proc. Biochem., 45, 1664-1671. DOI: 10.1016/j. procbio.2010.06.018.

10. Vanasperen, K. (1962). A Study Of Housefly Esterases by Means Of a Sensitive Colorimetric Method. J. Insect Physiology., 8, 401. DOI: 10.1016/0022-1910(62)90074-4.

11. Fernandez, N.F., Sansone, S., Mazzini, A. \& Brancaleon, L. (2008). Irradiation of the porphyrin causes unfolding of the protein in the protoporphyrin IX/beta-lactoglobulin noncovalent complex. J. Phys. Chem. B. 112, 7592-7600. DOI: 10.1021/jp710249d.

12. Kapp, E.A., Daya, S. \& Whiteley, C.G. (1990). Protein-Ligand Interactions - Interaction Of Nitrosamines with Nicotinic Acetylcholine-Receptor. Biochem. Biophys. Res. Commun., 1(67), 1383-1392. DOI: 10.1016/0006-291x(90)90676-E. 